\title{
THE ROLE OF LITERATURE IN CURBING THE SPREAD OF COVID-19
}

\section{Uche Nnyagu $(\mathrm{PhD})^{1}$, Udogu Christiana Obiageli $(\mathrm{PhD})^{2}$}

\section{and Onunkwo Benedette Ngozi ${ }^{3}$}

${ }^{1}$ Department of English, Nnamdi Azikiwe University, Awka

${ }^{2}$ Department of English, Nwafor Orizu College of Education, Nsugbe

${ }^{3}$ Department of English, Federal College of Education (T), Umunze

Cite this article:

Uche N., Udogu C.O., Onunkwo B.N. (2022), The Role of Literature in Curbing the Spread of COVID-19. African Journal of Social Sciences and Humanities Research 5(1), 46-54. DOI: 10.52589/AJSSHR0C4RTRZA.

\section{Manuscript History}

Received: 20 Jan 2022

Accepted: 5 Feb 2022

Published: 8 March 2022

Copyright $\odot 2022$ The Author(s). This is an Open Access article distributed under the terms of Creative Commons Attribution-

NonCommercial-NoDerivatives 4.0 International (CC BY-NC-ND

4.0 ), which permits anyone to share, use, reproduce and redistribute in any medium, provided the original author and source are credited.
ABSTRACT: Coronavirus is one pandemic that has thrown the entire world into misery, fear and untold hardship. It has caused the death of many people all over the world. Unlike the dreaded HIV, coronavirus has no definite cause and its mode of spread is almost mystery. When contacted, HIV can be managed by those living with the virus and they can go about their normal businesses without fear of transmission. Coronavirus brought panic into the world, leading to total lockdown all over the world. The entire world was thrown into confusion and since 2020, efforts have been on top gear to demystify the virus as well as stop the spread. The researchers are of the view that literature is the effective means of fighting the virus and in this article, they have chronicled the dangers of the illness and proffered solution on how the spread of the virus could be tackled using Literature.

KEYWORD: COVID-19, Literature, Language, WHO, Environment 


\section{INTRODUCTION}

Literature is an indispensable weapon for fighting demeanor in any society. Although literature is a work of art, the author draws his inspiration from what happens around him. So writers aptly mirror the happenings in their literature. Inspired by realities in the society, the writer shapes the literature I such a way the literature would have positive effect on the society. According to Abram, M.H, in its application to imaginative writing, "literature" has an evaluative as well as descriptive function, so that its proper use has become a matter of contention. Modern critical movements, aiming to correct what are seen as historical injustices, stress the strong but covert role played by gender, race, and class in establishing what has, in various eras, been accounted as literature, or in distinguishing between "high literature" and the literature addressed to a mass audience (152).

By high literature, Abrams is of the view that literature should educate and not solely to entertain. Abrams belief that literature should entertain is widely uphold by many critics. Since the Neoclassical era, literature has always been used for sanitizing the society as well as proffering solution. Literature does this by fiercely attacking the ills in the society in such a way that the targeted would feel the bite and make amends. In his Literature and Society, Uche Nnyagu affirms that literature acts as a gadfly in societies represented by the author. John Dryden, a neoclassical writer and critic, responding to the function of literature, believes that literature is used to attack ills and that to be able to achieve the result, the literature should attack in such a way that the targeted should feel the bite.

Literary artists are enjoined by Chinua Achebe in "The Novelist as a Teacher" to use their literature to right the wrongs in the society. Thus a writer must reflect and interpret his society, his world; he must also provide inspiration and guidance and challenge. People believe what they read and so, writers put down contemporary ideas and happenings in their literature so that readers read and get exposed. A writer is believed to be a custodian, and he is a teacher teaching the audience what they ought to know about the society. Writers write based on experience they gather and transformations and occurrences in the society provide inspiration to the writers. Today, covid-19 is a novel virus, writers research about that and write about it with the aim educate the masses. It is obvious that literature would not be possible without language.

According to Wikipedia, a language is a structured system of communication used by humans, based on speech and gesture (spoken language), sign, or often writing. It is the principal method of human communication, consisting of words used in a structured and conventional way and conveyed by speech, writing, or gesture. Language is a natural gift human beings are endowed with so every physiologically and mentally typical person acquires in childhood the ability to make use, as both sender and receiver, of a system of communication that comprises a circumscribed set of symbols. What this entails is that language is basically acquired and not learned. God understood the indispensability of language among people who were created in his own image and likeness and he also understood that without language, human beings become beasts, thus on creation, he gave human beings language to enable them live gregariously. A child born in a particular environment grows up in the midst of the people and soon, he begins to speak the language of the people without the language being taught to him or her. This is because language is a natural gift from nature to man. The very first language the child speaks as the child begins to talk is the language of the immediate environment, known as the mother tongue and it is acquired and not learnt. The need for a second language 
arises as one aspires to associate and intermingle with other people outside one's immediate society. At this point, one learns and not acquires the second language.

Human beings all over the world are sociable, glaringly different from the lower animals basically because of the unique feature - gregariousness. Albeit in various societies of the world, people have dissimilar ways of life but persons from different societies still travel to places where their language is not spoken. Soon after they had come into the new environment, they intermingle with other people who share different ways of live. This is where literature comes in. Literature uses language as a means of communication to expose the tenets of a particular society to foreigners so that one coming newly to the society and who has read a work of art authored by a person from the society must have understood a bit about the society. When one travels to an alien society, all he does is to first, learn the language of the new environment so as to be able to be assimilated in the society. Without language, no literature would be possible.

COVID-19 was a global pandemic and so literature writers need global language to write about it so that the aim would be achieved. A stranger in a new environment needs to master the language skills of the language of the new environment to be able to survive in the new environment. Without the knowledge of the basic language skills of the new society, the new entrant into the society will certainly not be different from the lower animal. Apart from the ability to think and reason well, another major thing that distinguished man from the lower animal is language. Literature is that which differentiates human beings from animals and literature enables one to understand and master a language and literature also helps one to understand and master the tradition and culture of a new environment. This article is centred on contemporary issue - the epidemic ravaging the entire world and. Language and literature are two inseparable concepts with language very indispensable for literature to exist.

\section{HISTORY OF COVID-19}

COVID-19, otherwise known as coronaviruses are a family of viruses that range from the common cold to severe acute respiratory syndrome (SARS). Many health experts believe that the new strain of coronavirus likely originated in bats or pangolins. The first transmission to human beings was in Wuhan, China. On the outbreak of the dreaded COVID 19, illness caused by SARS-CoV-2, every citizen of every country was enveloped in horror as a result of the enormous danger of the novel global threat. Since the first transmissions, the virus has mostly spread through person-to-person contact. COVID-19 is an acronym coined by the World Health Organization derived from "coronavirus disease 2019". COVID-19 is thus defined as illness caused by a novel coronavirus called severe acute respiratory syndrome coronavirus 2 (SARSCoV-2; formally called 2019-nCoV), which was first identified amid an outbreak of respiratory illness cases in Wuhan City, Hubei Province, China.

COVID-19 was initially reported to the World Health Organization (WHO) on December 31, 2019. On January 30, 2020, the World Health Organization declared the COVID-19 outbreak a global health emergency. On March 11, 2020, the World Health Organization declared COVID-19 a global pandemic, its first such designation since declaring H1N1 influenza a pandemic in 2009. In the recent years, COVID-19 is the most dreaded disease which has enthroned panic and fear in the whole world. Coronavirus was dreaded more that the deadly 
disease HIV basically because it has no cure and it kills the victim soon after causing serious threat to the victim. Unlike HIV, coronavirus cannot easily be managed and its mode of transmission is not only via one means. Many countries of the world are suggesting various levels of containment in order to prevent the spread of coronavirus, or COVID-19. With these worries, schools and universities closed and many resorted to online platforms and remote education. It was a mystery to many how information about COVID-19 spread to all parts of the world resulting in blockages of borders to prevent immigration and emigration with the aim to stop the spread of the ailment. Since its first case in China, COVID-19 has spread to almost every country worldwide. According to World Health Organization, 167515 global cases were reported, including 6606 deaths, as of March 16, 2020. The worry around the virus, and the effort to contain it, stems from a lack of previous experience with it. Since the virus is previously unknown, highly contagious, and passes early from one person to the next, public health and government officials around the world are working hard to contain the spread of the virus. The question is how did people get information about the dangers of the disease? And how is the information pertaining to COVID-19 transcended? Laurence Perrine disclosed that literature is the answer. According to him, literature uses emotive language to make hidden facts known globally. He believes that every good literature shouldn't only entertain but also educate the audience. He sees education (enlightenment) as a major duty of literature arguing that any literature that offers only entertainment is comparable to a miniature golf or ping-pong.

Matthew Arnold, a Victorian critic with Romantic impulse insists that literature is the only thing that helps man to understand the society. As he puts it, literature is the only thing that helps man to understand himself. Literature does this by interpreting life to him. Today, many works of literature have been written and published in many languages on the deadly ailment. Some of the novels merely reveal the mystery behind the spread of the virus, others are written to show how terrible the virus is. In all, the essence of the literature is to educate the masses on the best way to avoid the spread of the virus in the interest of the society.

\section{The Impact of Literature on the Modern Society}

David Ker in his Literature and Society quotes Jean Paul Sartre as believing that literature is useful in the modern society. According to Sartre in Ker, like morality, literature needs to be universal. So that the writer must put himself on the side of the majority of the two billion starving, if he wishes to be able to speak to all and be read by all. Failing that, he is at the service of a privileged class and like it, an exploiter (3). To be able to pass the information and educate the masses, literature is written in a language understood by the targeted audience. The impact of literature in the modern society cannot be overemphasized. According to literary theorist, Victor Shklovsky, the purpose of literature (art, more broadly) is to defamiliarize, or make the familiar feel strange. It causes the reader to regard reality from a different perspective. This can be unsettling for the reader, who is attached to familiar ways of knowing to the world. But by provoking the reader to see the world as strange, literature allows the reader to see the world anew. Defamiliarity, thus, leads to new insights.

According to Uche Nnyagu in his Literature and the Literate, literature creates empathy and understanding. He believes that literature writers use imaginary persons to represent real persons in real society. Like in real life, the imaginary characters struggle to come out of imposed conflicts and the members of audience read and decode the real society and understand how to tackle similar problems through the struggles of fictional characters. This is why many critics believe that literature improves human mind so that when someone reads, he or she 
literally reads the mind of others. This is because through the character's internal thoughts which the reader seeks to access, the mind of individuals in real life is understood and an individual in real life understands a lot about himself or herself, others and the society at large. To Kennedy, X.J, Dana Gioia and Mark Bauerlein in their Handbook of Literary Terms: Literature, Language, Theory, Literature helps to improve society as it imparts a world spun out of the author's imagination. They believe that although literature could be based on imagination, it thrives on reality and the author fictionalizes reality in a way that improvement is made. Similarly, literature demystifies the author's society in such a way that one who has not been to a society tends to understand the society via literature. A Yoruba man who had not been to Igbo society but had read Chinua Achebe's Things Fall Apart disclosed to her friends that she would like to marry two Igbo women. Amazed, one of his friends cared to know why he preferred Igbo women as his wives, the Yoruba man said that Igbo women are submissive to their husbands. Amazed again, his friends asked him how he managed to know much about Igbo women when he has not been to Igbo society and has not known Igbo people well, the Yoruba man responded that he does not need to live in Igbo society to understand the way of life of the Igbo when one could read a good novel authored by an Igbo. According to him, Okonkwo in Things Fall Apart married three wives and the three wives of Okonkwo remained submissive to him. The Yoruba man is right but definitely, Achebe in the novel, represented life as it was lived in early nineteenth century. It is incongruous to align Things Fall Apart with the contemporary Igbo society. The world is dynamic and the Igbo society too, is dynamic. Today, Igbo ladies abhor polygamy; no Igbo woman would like to, like women in the time of Achebe, share the love of her man with any other woman. Today, polygamy is almost seen as a taboo in many Igbo and some African societies because the white man, after colonization, made Africans believe that their tradition, including polygamy was evil. Many Igbo people today who were ignorant of the way of life of the Igbo in the past would read Chinua Achebe's Things Fall Apart and see life as it was lived by the traditional Igbo people in the Igbo society then. That is the function of literature - to enable us understand life.

Literature allows a person to step back in time and learn about life on earth from the ones who walked before us. We can gather a better understanding of culture and have a greater appreciation of them. We learn through the ways history is recorded, in forms of manuscripts and through speech itself. Scholars are of the opinion that the level of civilization a society attains is dependent on the literacy level of the members of the society. Recall that the concept literature is an art. As an art, literature denotes that which is written and it includes works in various non-fiction genres, such as biography, diaries, memoirs, letters and the essay. This is literature on the broader sense which further includes non-fictional books, articles or other printed information on a particular subject. This being the case, literature concerns everyone who is able to read and understand a written document. Some societies of the world remain underdeveloped because of the illiteracy level of their citizens who are unable to read things written about how other societies attained the height of development that they had attained and then follow the same means to develop. Literature is simply an eye opener and as Matthew Arnold observed, it helps to disillusion a folk who had been living in illusion. A cursory study of Chinua Achebe's Things Fall Apart reveals to the audience that the Igbo in the nineteenth century were mainly polygamists and that the women were not jealous sharing the love of their husbands. Okonkwo is used by Achebe to symbolize the typical Igbo. He married three wives and the three wives were submissive to him. We understand a lot about the traditional Igbo people in a traditional Igbo society through Chinua Achebe's Things Fall Apart. Ernest Emenyonu in his The Rise of the Igbo Novels writes that Achebe's novels, including Things 
Fall Apart, are set in historical perspective and reflect the process of change in Igbo society from the mid-nineteenth century to the 1960s, the first post-independence decade. According to him, "Things Fall Apart (1958), is set at a time when the early Europeans were first coming to Igbo land (104). Okonkwo in the novel married three wives and he is held in high esteem unlike his monogamous father Unoka who is rather derided for being lazy. Unoka's laziness made him unpopular and as a result, couldn't as other typical Igbo men, marry more than one wife. Unoka being derided for having only one wife is a clear indication that in a typical Igbo society during the era, it was almost a bad thing to have only one wife.

Literature on the narrower sense, though a work of art, mirrors society and allows us to better understand the world we live in. It acts as a form of expression for each individual author. An author is inspired by what happens around him, hence literature aptly mirrors the author's society. Writers of literature, according to Chinua Achebe in his "Novelist as a Teacher", act as teachers and educators who use their literature to expose certain occurrences in their societies and as well, use their invented characters to educate the audience on the impending dangers of the incongruities.

Literature is a source of entertainment. Readers of novels get entertained, we are equally entertained when we watch movies or listen to performers of poetry. These are appendages of literature. Even before the coming of the Europeans to Africa, in many parts of Africa, raconteurs are paid to entertain the teaming audience with interesting stories. But then, entertainment is not the top priority of literature. Critics believe that literature, above other functions, educates. According to Bernard Shaw, a good literature is that whose major priority is to educate. He admits that literature entertains but when the sole function of literature becomes entertainment solely, such literature worth no attention. In his words, if drama (Literature) offers only entertainment without enlightenment, it seems to me as though it is a mere waste of time. By enlightenment, he believes that literature should educate the audience about the happenings and occurrences in a society and then proffer a solution to any envisaged ill.

\section{Curbing the Spread of the Coronavirus through Literature}

It has been stated somewhere that literature acts as a gadfly in a given society. This entails that literature is interested in the societal ills and it criticizes the ills in such a way that there would be reformation. Today, coronavirus is a cankerworm ravaging the entire world. People's lives are endangered and every society is in perpetual fear heralded by the outbreak of the virus. Borders are closed to stop movement of people from a place to another as to ensure the stoppage of the spread of the virus. Continued blockage of borders would rather cause more hardship to the people as continued lockdown would not do the people of the world any good. With language, measures on how to curb the spread of coronavirus are relayed to those who understand the language. Part of the measures of curbing the spread of the virus includes:

i. Wearing of the facemask

ii. Constant hand washing in running water

iii. Sanitization of the hand

iv. Maintaining social distancing 


\section{v. Avoiding handshake and hugging \\ vi. Avoiding crowded areas etc}

The above measures are to be strictly adhered to ensure that the society is rid off the pandemic. To be able to disseminate the information, language, written or oral is required. With spoken language only, the information could not be effectively disseminated with effective result. Literature writers use language effectively in their literature to achieve good results. The onus therefore, is on the writers to write about the dangers of the virus, the spread of the virus and the possible means of avoiding the spread in their works. To pass the information well, the writer of a novel, for instance, invents characters who are recalcitrant and who refuse to observe the precautionary measures of COVID-19 and so, they end up contacting the virus.

Literature writers, when in their works of art, they hype the sufferings of those who out of their deliberate mistakes and recalcitrance, contacted the virus, the pains they pass through is equally hyped, the audience reads the literature and get educated. Literature is read and the message is taken to be true. This is why it is believed that literature reforms. Anybody who reads such didactic works of art and sees the hyped sufferings of the careless characters and of course, how they ended tragically as fantastically presented by the writer would certainly be educated and corrections be made. Critics believe that literature writers have as their responsibility, to use their works to educate.

Chinua Achebe in "Novelist as a Teacher," enjoined African writers to mirror their societies in their literature and ensure that they use their literature to reform their societies. According to David Ker in his Literature and Society in Africa, "Achebe's conception of the role of the artist in Africa is not different from that of most of his fellow writers. The modern African writer is the product of his species. This is best exemplified in Wole Soyinka. At the AfricanScandinavian Writers' Conference in Stockholm in 1967, Soyinka berated his fellow African writers for being more insensitive than writers elsewhere to the contemporary universal collapse of humanity" (7). These African critics underscore the indispensability of literature as a means of reformation and education. Ker disclosed that the writer cannot be excused from the task of re-education and re-generation that must be done. According to him, the writer should march right in front. By marching right in front, Ker is of the view that writers research about everything happening in their society and write about them in such a way that through the writing, the members of the audience are educated.

In early 2020, after a December 2019 outbreak in China, the World Health Organization identified SARS-CoV-2 as a new type of coronavirus. The outbreak immediately spread round the entire world. The spread was rapid, mainly through person-to-person contact, with the virus ranging from mild to deadly. Since the outbreak of the COVID-19, many writers have in their various works of art, mirrored the dangers of the virus as well as X-raying the means the virus spread all with the intent to curb the spread. Chris Bohjalian, a writer and a newspaper contributor, affirming that literature is the best weapon for fighting the spread of coronavirus, says:

Someday soon, we are going to be turning the pages of this newspaper and will spot a review for a book about the pandemic spring of 2020. Already, the nonfiction accounts are on their way, with their chronicles of the virus's spread across the globe and the missed opportunities to 
contain it. As the New York Times recently reported, Fang Fang's "Wuhan Diary" arrived this month, with Debora MacKenzie's "Covid19: the Pandemic that Never Should Have Happened" not far behind.

The novels will come next.

I say this because we novelists depend upon journalists and historians to help us understand what really happened. Inside the fictional structures I build are framing, wiring and plumbing that make a house a home, and a lot of what resides behind the fictional wallpaper and Sheetrock is what actually happened. Or could happen

Bohjalian, by the above statement, is of the opinion that a literature writer does not work in isolation, he depends on the journalists and historians as well as on his physical experience. The partnership can only be possible when language is involved. Christopher Bollen in an article about Chris Bohjalian's thriller novel The Red Lotus, writes that Bohjalian possesses one of the best-turned antennas in contemporary fiction for absorbing the troubles, forces, terrors, fortunes, and yes, plagues that turn the world. The Red Lotus, is described as a novel packed with deadly pathogens and paranoiac animal-to-human transmissions, was released right as New York City was shutting down over the spread of COVID-19. The author profusely chronicled the dangers of the virus as well as educated the audience on the on the precautionary measures. Bohjalian's and other literary works have contributed a lot in fighting against the spread of the pandemic. Without literature, obviously a society is dead. Without literature writers in a society, the society keeps wallowing in perpetual darkness. Aristotle had earlier looked at literature as an imitation of life fantastically woven to reform the author's.

Ker says that the old questions about the efficacy of literature in solving our contemporary problems have reappeared also in the form of questions about the relevance of our literature written in English to contribute materially to the development of our culture (33). In this era of coronavirus, writers all over the world have the responsibility of incorporating the theme of coronavirus pandemic in their works of literature. According to Robin Brooks, an assistant professor in the Department of African Studies, after COVID-19 changed the world, Brooks decided the edition could cover works from the past in ways that examine what's happening today, particularly issues surrounding Black lives. Speaking on the responsibility of writers in the face COVID-19, Brooks said that some people can see it in the sad sense, that some of the very issues that they have been tackling in their work for decades are still here. They're still major issues within the lives of Black people, of course in the United States, but around the world... This COVID-19 moment has outlined them but their work is still very much relevant to what we are facing in our lives right now.

\section{CONCLUSION}

Covid-19 has brought a lot of hardship to the entire world. The economic and social disruption caused by the pandemic is devastating. Millions of people are at risk of falling into extreme poverty, while the number of poorly nourished people, currently estimated at about seven million by the end of 2020. The year 2020 thus remained a red letter year in the annals of the whole world. It was a year of total lockdown occasioned by the outbreak of the novel virus, COVID-19. The COVID-19 pandemic hogged the headlines through much of 2020, and we 
still haven't seen the end. COVID-19 enthroned perpetual fear in every society of the world. Intra and inter country migration was banned and hardship became an uninvited visitor to every home. If nothing is done to put an end to the spread of the virus, then the entire world would remain in perpetual fear. Education sectors have a great works to do to ensure that the pandemic is raid to rest. Literature has always remains an indispensable means of fighting any societal ill. Literary writers are gadflies and as such, they are interested in misdeeds and abnormalities in the society with the intent to remedy such through their writing. Now that covid-19 is a threat ravaging the entire world, literary artists are encouraged integrate the theme of the threats of covid-19 and the mode of spread in their literature. The way the writers hype the dangers of the threat of covid-19 will make the entire society understand the need to follow the precautionary measures as not to fall victim.

Literature writers must always remember that the essence of writing is to communicate. When literature fails to communicate, it becomes effort in futility. To be able to communicate, writers of literature in addition to incorporating the theme of covid-19 in their novels, should use appropriate language that would enhance understanding. Literature should be made to inform and not basically to impress. To inform, simple and apt language such that Achebe and his likes used in their novels that made them recognized as good writers should be used.

\section{REFERENCES}

Abrams, M. H. A Glossary of Literary Terms. Boston: Thomson Wadsworth, 2005. Print.

Achebe, Chinua. "Novelist as a Teacher" in Olaniyan, Tejumola and Ato Quayoson's African Literaature: an Anthology of Criticism and Theory. UK: Blackwell, 2002. Print.

Achebe, Chinua. Things Fall Apart. London: Heinemann, 1958. Print.

Bohjalian, Chris. The Red Lotus. New York: Penguin, 2020. Print.

Emenyonu, Ernest. The Rise of the Igbo Novel. Ibadan: Heinemann, 1987. Print.

Kadiri, G.C. "Style in the Nigerian Novels". In E.J. Otagburuagu, L.C. Ogenyi\& J.C. Ogbodo (eds.), Exploration on Styles, Stylistics and the Language of Literature. Enugu: Benak Publishers, 2014. Print.

Kennedy, X. J, Dana Gioia \& Mark Bauerlein. Handbook of Literary Terms: Literature, Language, Theory. New York: Longman, 2008. Print.

Ker, David. Literature and Society. Ibadan: Spectrum, 2004. Print.

Nnyagu, Uche. Literature and the Literate. Germany: Scholars, 2018. Print.

Nnyagu, Uche. Mediocrities. Nsugbe: Alpus Prints, 2019. Print.

Perrine, Laurence. Literature: Structure, Sound and Sense 3rd edn. New York: Harcourt Brace, 1978.

Robbins, L. A. Grammar and Style at your Finger-tips. USA \& England: Penguin Group, 2007. Print.

Sapir, Edward. Language: an Introduction to the Study of Speech. New York: Harcourt, Brace and Company. 1921. Print.

Shklovsky, Victor. Bowstring: on the Dissimilarity of the Similar. Moscow: Dalkey, 2011. Print.

Sweet, Henry. History of Language. New York: Dent JM, 1916. Print.

Widdowson, H. G. Stylistics and the Teaching of Literature. London: Longman, 1975. Print. 